\title{
PROFESSIONALISM IN FISHERY BIOLOGY
}

\author{
Roger W. Bachmann \\ Department of Fisheries, University of Michigan \\ Ann Arbor, Michigan
}

FIRM IN THE BELIEF that private, professional opportunities and rewards for fishery scientists need universal enhancement, Dr. Karl F. Lagler and Robert O. Beatty originally undertook this survey. The idea was to determine the extent to which the use of men in fisheries might be developed on a professional basis through servicing the owners of private fishing waters. In many areas of the country, for example, it was known to be impossible for private holders of water rights to secure the help which they needed and desired.

The procedure in this survey was to submit a questionnaire to chiefs of fishery departments in the 48 States during the fall of 1953. Also censused were a few private investigators who were known to be engaged periodically in consulting work.

The questions, a sense-summary of the replies, and a few illustrative quotations follow:

Is your department prohibited from providing direct help for the improvement of fishing to the owners of private waters?

About two-thirds of the States have no restrictions of this nature. The remainder are prohibited, either by law or by public pressure, from spending public money on private waters. A common expression in the replies was, "Our policy has always been to stay clear of private waters unless the owner agrees to leave the water open to public fishing. "

How many requests do you receive each year for direct help on private waters involving other than routine requests which can be serviced permissably by mail ?

The estimates ran from 10 to 4,000 requests, averaging about 50 per year. There seemed to be no correlation between the sizes of the States and the number of requests. The largest numbers were in the South and East. In one State it was felt that the number of requests received would be larger if people were aware of the service and its availability.

How many of these requests were you unable to meet?

These estimates ran from 0 to 100 percent, averaging about 50 percent. Here there was a large variation among the States, with no definite correlation between the number of requests and the percentage of requests which were not met.

Do private pond owners in your State have any other source of on-the-ground aid in their sportfishery management problems ?

About half of the States replied, "Yes," listing the U. S. Soil Conservation Service as the major agency concerned. Also named were the U. S. Fish and Wildlife Service, county agents, a few private agencies, and some university professors and state biologists who consult-both free and for a fee--in their spare time. 
Can you stock fish from State hatcheries in private waters?

About half the States can, though many have restrictions, as initial stocking only, warm-water fish only, etc. In some, private waters may be stocked if the public is allowed to fish; in others, stocking may be done in special cases only. Of States that permit planting public-owned fish in private waters, only one charges for the fish.

Do your personnel do on-the-ground survey or management work on private waters?

Three-quarters of the States answered, "Yes." Some were limited to farm ponds; some were limited as to extent of services they could render. Most of this work is done on State time, with no charge to the pond owner except where he paid for materials--poisons, fertilizer, etc.--used.

What services are requested or implied in such private-water requests?

\section{SUMMARY OF SERVICES REQUESTED}

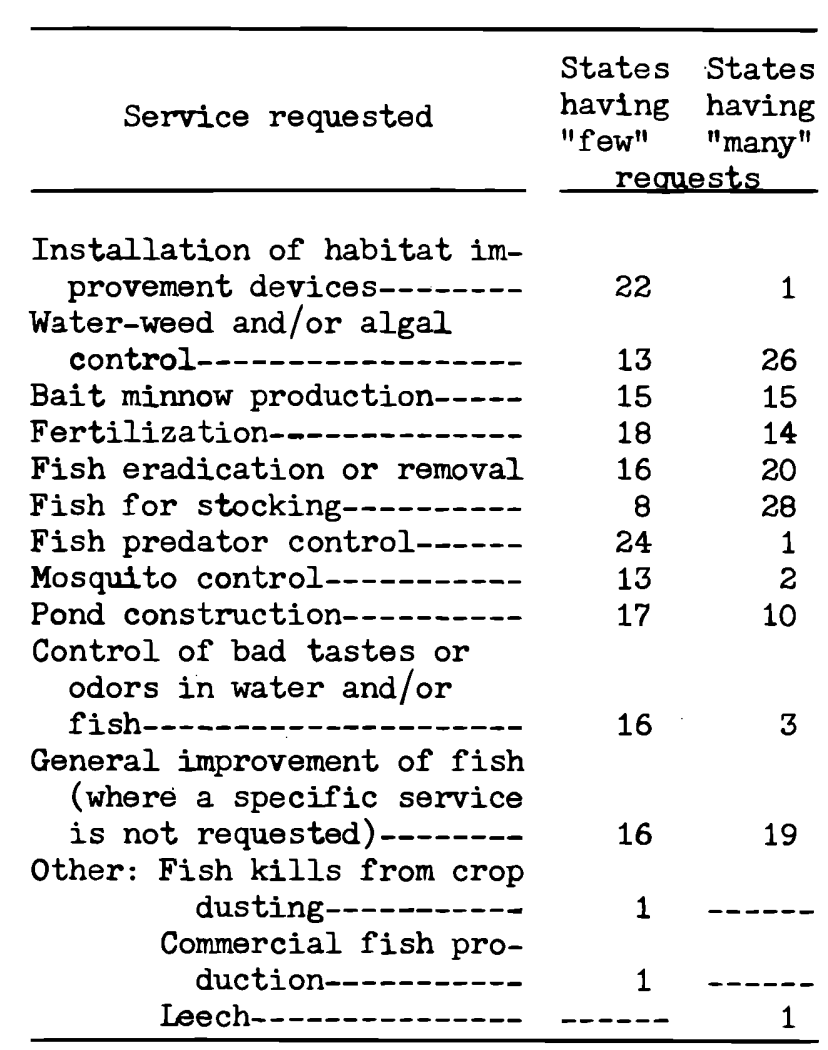

Most of the requests for service involved water-weed control, fish eradication or removal, fish for stocking, and general all-round appraisal, help, and guidance. From 19 to 28 States listed the foregoing as "many request" kinds of service; 10 to 15 assigned the "many request" classification to bait minnow production, fertilization, and pond construction.

Would you welcome a privately financed and operated sportfishery or management and consulting service, staffed by recognized and accredited biologists, operating only on private waters, and to which you could refer requests for help from private owners which you are unable to service to the fullest extent desirable?

About 80 percent answered, "Yes"; those that answered negatively qualified their replies. Some believed that the demand in their State was insufficient to warrant such a service. Two felt that the job should be done through their own departments; one believed that the biologists already doing part-time consulting would resent the competition.

If such a service were established on a nationwide basis and carefully operated so as not to conflict with or in any way duplicate or disturb fisheries or water-management policies or programs in your State, would you or members of your staff be willing to accept an occasional investigatory or management assignment, on own time, for fee plus expenses?

Two-thirds would like to participate in a program of this type. Many of those who replied negatively gave as reasons laws or departmental policies which would prohibit their participation. One felt that only fulltime men should be used.

Guesstimate the number of private water owners in your State who might need such a service.

The answers ranged from 10 to 50,000 , with the majority distributed between 50 and 5,000 . 
Guesstimate the number of private water owners in your State who might use such a service if offered at reasonable rates.

These estimates ran from 0 to 2,000 , with most of them falling in the 10-pond to 100-pond range. Owing to the nature of the questions and the fact that only half of the States gave any estimates at all, it is doubtful that the preceding estimates are of much value.

By way of summary, do you feel that there is a place in the sportfishery and water-management picture today for a counseling and management service, following standard and accepted procedures and providing sound management programs $\overline{\text { for }}$ the owners of private waters?

About 90 percent thought that such a service would be beneficial. Those who dissented thought that the existing agencies should handle the job.

An affirmative statement of interest was: "Especially in heavily populated districts and around large cities where wealthy people are interested in private water leases and money is no object in the desire to improve fishing."

A negative comment was: "No, if our own service here can be expanded; yes, otherwise."

The most prevalent sense was: "A good management service would be wonderful, but even the people with money in their State expect the State and Federal government agencies to do it for them free."

\section{Conclusions}

Keeping in mind the limitations of a survey of this type, I believe that the following conclusions can be reached:

1. There is a need for professional fishery biologists who can give aid and advice to private pond owners.

2. In most areas a private consulting service would be welcomed by the State agencies concerned with fishery management.

3. The extent to which a service of this type would be profitable depends on the area concerned. In some areas competition with State agencies and the low potential market would eliminate a venture of this type. The data at hand indicate that the greatest opportunities lie in the eastern and southern portions of the United States.

As the fishing pressure increases on public waters, the growth of private professional opportunities for fishery scientists seems inevitable. From the data at hand, it appears that the time is ripe for the establishment of biological consulting services in the areas where the State agencies are not meeting the demands of the private water owners. It may be advisable for a special committee of the American Fisheries Society or the Sport Fishing Institute to undertake the establishment of codes of sound practice and recompense.

On the basis of laboratory tests, a sequentially pulsed array that has but a single row of electrodes appears to be a very promising means of diverting salmon fingerlings from dangerous areas at dams. Under the controlled conditions of the laboratory, a duty-cycle range from 0.06 to 0.10 has been effective in guiding these small finge rlings. To secure such a range, it is necessary to energize the electrodes only 6 to 10 percent of the time. As this low power requirement involves relatively low expenditures for electricity and for maintenance of equipment, there is reason to believe that guiding arrays thousands of feet in length would be feasible--and perhaps for all sizes of fingerlings. 